\title{
Mucilaginibacter daejeonensis sp. nov., isolated from dried rice straw
}

Correspondence

Chun-Hwi Cho

kafco1002@hanmail.net

\section{Dong-Shan An, ${ }^{1}+$ Cheng-Ri Yin, ${ }^{2} \dagger$ Sung-Taik Lee ${ }^{1}$ and Chun-Hwi Cho ${ }^{3,4}$}

\author{
${ }^{1}$ Department of Biological Sciences, Korea Advanced Institute of Science and Technology, 373-1, \\ Guseong-dong, Yuseong-gu, Daejeon 305-701, Republic of Korea \\ ${ }^{2}$ Key Laboratory of Organism Functional Factors of the Changbai Mountain, Ministry of Education, \\ Yanbian University, Yanji 133-002, PR China \\ ${ }^{3}$ Korea Agriculture Fertilizer Corporation Biochemistry Research Institute, ChungBuk 373-831, \\ Republic of Korea \\ ${ }^{4}$ Department of Bio-Environmental Chemistry, Chungnam National University, Daejeon 305-764, \\ Republic of Korea
}

The genus Mucilaginibacter was proposed by Pankratov et al. (2007) to accommodate species characterized by Gramnegative, non-motile rods that are facultatively aerobic, produce large amounts of extracellular polymeric substances (EPS), are capable of fermenting glucose and sucrose, hydrolyse pectin, xylan, laminarin, chondroitin 6-sulfate, gellan gum, pullulan and starch, are negative for $\mathrm{H}_{2} \mathrm{~S}$ production from thiosulfate or indole from tryptophan and contain iso- $\mathrm{C}_{15: 0}$, iso- $\mathrm{C}_{17: 0} 3-\mathrm{OH}$ and summed feature 3 (iso- $\mathrm{C}_{15: 0} 2-\mathrm{OH}$ and/or $\mathrm{C}_{16: 1} \omega 7 c$ ) as major fatty acids and MK-7 as major menaquinone. At the time of writing, it comprises two recognized species, Mucilaginibacter paludis and Mucilaginibacter gracilis (Pankratov et al., 2007). In this study, we have characterized the novel Mucilaginibacter-like strain, Jip $10^{\mathrm{T}}$, which was isolated from dried rice straw in a field in Daejeon city in South Korea.

Strain Jip $10^{\mathrm{T}}$ was isolated from dried rice straw via direct plating onto R2A agar (Difco). Single colonies on these

TThese authors contributed equally to this work.

The GenBank/EMBL/DDBJ accession number for the 16S rRNA gene sequence of strain Jip $10^{\top}$ is AB267717. plates were purified by transferring them onto new plates and subjecting them to additional incubation for 3 days at $30{ }^{\circ} \mathrm{C}$. The purified colonies were tentatively identified by using partial $16 \mathrm{~S}$ rRNA gene sequences and maintained as a glycerol suspension $\left(20 \%\right.$, w/v) at $-70{ }^{\circ} \mathrm{C}$.

The Gram reaction was performed by the non-staining method as described by Buck (1982). Cell morphology was observed at $\times 1000$ magnification with a light microscope (Nikon) using cells grown for 3 days at $30{ }^{\circ} \mathrm{C}$ on R2A agar. Catalase activity was determined by bubble production in $3 \%(\mathrm{v} / \mathrm{v}) \mathrm{H}_{2} \mathrm{O}_{2}$ and oxidase activity was determined using $1 \%(\mathrm{w} / \mathrm{v})$ tetramethyl $p$-phenylenediamine. Carbon-source utilization and enzyme activities were tested by using the API 20NE, ID 32 GN, API $50 \mathrm{CH}$ and API ZYM test kits (bioMérieux). The ability to use nitrate as an alternative terminal electron acceptor was tested in serum bottles by adding sodium thioglycolate $\left(1 \mathrm{~g} \mathrm{l}^{-1}\right)$ to $\mathrm{R} 2 \mathrm{~A}$ broth and replacing the upper air layer with nitrogen gas. The anaerobic nitrate reduction test to determine the final electron acceptor was performed in serum bottles by adding sodium thioglycolate $\left(1 \mathrm{~g} \mathrm{l}^{-1}\right)$ and $10 \mathrm{mM} \mathrm{KNO}_{3}$ to R2A broth, under nitrogen gas. Growth at different 
temperatures $\left(4,15,20,25,30,37\right.$ and $\left.42{ }^{\circ} \mathrm{C}\right)$ and at various $\mathrm{pH}$ values $(\mathrm{pH} 5.0-10.0$ at intervals of $0.5 \mathrm{pH}$ units) was assessed after 5 days of incubation. Salt tolerance was tested on R2A agar supplemented with 1$10 \%(\mathrm{w} / \mathrm{v}) \mathrm{NaCl}$ after 5 days of incubation. Growth on nutrient agar, trypticase soy agar (TSA) and MacConkey agar was also evaluated at $30{ }^{\circ} \mathrm{C}$.

Cells of strain Jip $10^{\mathrm{T}}$ were facultatively aerobic, Gramnegative, heterotrophic, non-motile, non-spore-forming rods. The strain did not grow on nutrient agar or MacConkey agar. The ability to reduce nitrate was absent. Other physiological characteristics of strain Jip $10^{\mathrm{T}}$ are summarized in the species description and a comparison of selective characteristics with closely related species is shown in Table 1.

For the measurement of $\mathrm{G}+\mathrm{C}$ content of the chromosomal DNA, genomic DNA of the novel strain was extracted and purified as described by Moore \& Dowhan (1995), degraded enzymically into nucleosides and analysed as described by Mesbah et al. (1989) using reversed-phase HPLC. Isoprenoid quinones were extracted with chloroform/methanol $(2: 1, \mathrm{v} / \mathrm{v})$, evaporated under vacuum conditions and re-extracted in n-hexane/water $(1: 1, \mathrm{v} / \mathrm{v})$. The crude n-hexane-quinone solution was purified using Sep-Pak Vac silica cartridges (Waters) and subsequently analysed by HPLC as described by Hiraishi et al. (1996). Cellular fatty acid profiles were determined from biomass harvested from one-tenth-strength TSA (Difco) after 3 days of incubation. The cellular fatty acids were

Table 1. Biochemical characteristics of strain Jip $10^{\top}$ and the type strains of Mucilaginibacter species

Strains: 1 , strain Jip $10^{\mathrm{T}} ; 2$, M. gracilis TPT18 ${ }^{\mathrm{T}} ; 3$, M. paludis TPT56 ${ }^{\mathrm{T}}$. Data for reference strains were taken from Pankratov et al. (2007). All three strains are positive for copious EPS production, acid production from D-fructose, D-galactose, D-glucose and maltose and catalase and oxidase activities. All strains are negative for indole production. All three strains assimilate D-glucose, sucrose and maltose, but not acetate, citrate, malate, mannitol, melibiose, propionate or valerate.

\begin{tabular}{|lccc|}
\hline Characteristic & $\mathbf{1}$ & $\mathbf{2}$ & $\mathbf{3}$ \\
\hline Growth at/in: & & & \\
$3{ }^{\circ} \mathrm{C}$ & + & - & - \\
$>1 \% \mathrm{NaCl}$ & + & - & - \\
Acid production from: & & & \\
L-Rhamnose & + & + & - \\
D-Mannose & + & - & + \\
Trehalose & + & - & + \\
D-Xylose & - & + & + \\
Assimilation of: & & & \\
$\quad$ Mannose & + & - & + \\
Gluconate & - & - & + \\
Salicin & + & - & + \\
$\quad$-Acetyl-D-glucosamine & + & + & - \\
G + C content (mol\%) & 40.4 & 47.2 & 48.9 \\
& & & \\
\hline
\end{tabular}

saponified, methylated and extracted according to the protocol of the Sherlock Microbial Identification System. The fatty acids were analysed by a gas chromatograph (Hewlett Packard 6890) and identified by the Microbial Identification software package (Sasser, 1990).

The G $+\mathrm{C}$ content of genomic DNA of strain Jip $10^{\mathrm{T}}$ was $48.1 \mathrm{~mol} \%$. MK-7 was the major respiratory quinone and MK-6 was a minor component. As shown in Table 2, the major fatty acids of this strain were iso- $\mathrm{C}_{15: 0}(26.5 \%)$, $\mathrm{C}_{16: 0}(9.3 \%)$, iso- $\mathrm{C}_{17: 0} 3-\mathrm{OH}(7.1 \%)$ and summed feature 3 (iso- $\mathrm{C}_{15: 0}$ 2-OH and/or $\mathrm{C}_{16: 1} \omega 7 c$ ) $(39.1 \%)$. These results supported the affiliation of strain Jip $10^{\mathrm{T}}$ to the genus Mucilaginibacter.

Extraction of genomic DNA was performed with a commercial genomic DNA extraction kit (Solgent) and PCR amplification of the 16S rRNA gene and sequencing of the purified PCR product were performed according to Kim et al. (2005). The full sequence of the 16S rRNA gene was compiled using DNASTAR. The 16S rRNA gene sequences of related taxa were obtained from GenBank. Multiple alignments were performed by using the CLUSTAL x program (Thompson et al., 1997). Gaps were edited in the BioEdit program (Hall, 1999). Evolutionary distances were calculated using Kimura's two-parameter model (Kimura, 1983) and phylogenetic trees were constructed by using the neighbour-joining method (Saitou \& Nei, 1987) using the MEGA 3 program (Kumar et al., 2004) with

Table 2. Fatty acid profiles of strain Jip $10^{\top}$ and the type strains of Mucilaginibacter species

Strains: 1 , strain Jip $10^{\mathrm{T}} ; 2$, M. gracilis TPT $18^{\mathrm{T}} ; 3$, M. paludis TPT56 ${ }^{\mathrm{T}}$. Data for reference strains were taken from Pankratov et al. (2007). -, $<1.0 \%$ of the total/not reported.

\begin{tabular}{|lccc|}
\hline Fatty acid & $\mathbf{1}$ & $\mathbf{2}$ & $\mathbf{3}$ \\
\hline Saturated & & & \\
$\mathrm{C}_{15: 0}$ & - & 3.2 & 4.5 \\
$\mathrm{C}_{16: 0}$ & 9.3 & 3.1 & - \\
$\mathrm{C}_{18: 0}$ & 1.7 & - & - \\
Unsaturated & & & \\
$\mathrm{C}_{15: 1} \omega 6 c$ & - & - & 1.2 \\
$\mathrm{C}_{16: 1} \omega 5 c$ & 5.9 & 5.8 & 2.6 \\
$\mathrm{C}_{18: 3} \omega 6 c$ & 1.3 & - & - \\
Branched-chain & & & \\
iso- $\mathrm{C}_{15: 0}$ & 26.5 & 15.7 & 32.2 \\
iso- $\mathrm{C}_{15: 0} 3-\mathrm{OH}$ & 2.2 & 1.8 & 3.2 \\
iso- $\mathrm{C}_{16: 0}$ & - & 1.5 & - \\
iso- $\mathrm{C}_{17: 0} 3-\mathrm{OH}$ & 7.1 & 8.9 & 13.1 \\
iso- $\mathrm{C}_{17: 1} \omega \mathrm{c}$ & 3.0 & - & 2.7 \\
anteiso- $\mathrm{C}_{15: 0}$ & 1.8 & 21.1 & 5.8 \\
anteiso- $\mathrm{C}_{17: 0}$ & - & 4.5 & - \\
Hydroxy & & & \\
$\mathrm{C}_{16: 0} 3-\mathrm{OH}$ & 2.3 & - & - \\
Summed feature $3 *$ & 39.1 & 24.7 & 21.5 \\
& & & \\
\hline
\end{tabular}

${ }^{*}$ Summed feature 3 comprises iso- $\mathrm{C}_{15: 0} 2-\mathrm{OH}$ and/or $\mathrm{C}_{16: 1} \omega 7 c$. 
bootstrap values based on 1000 replications (Felsenstein, 1985).

The nearly complete $16 \mathrm{~S}$ rRNA gene sequence (1469 bp) of strain Jip $10^{\mathrm{T}}$ was determined and subjected to comparative analysis. Phylogenetic analysis based on 16S rRNA gene sequences indicated that the isolate clustered with Mucilaginibacter in the phylum Bacteroidetes (Fig. 1). 16S rRNA gene sequence similarities between strain Jip $10^{\mathrm{T}}$ and the type strains of M. gracilis and M. paludis were 93.7 and $93.6 \%$, respectively. These values $(<97 \%)$ were low enough to place strain Jip $10^{\mathrm{T}}$ in a novel species in the genus Mucilaginibacter according to Stackebrandt \& Goebel (1994).

On the basis of the data and observations described above, strain Jip $10^{\mathrm{T}}$ should be assigned to the genus Mucilaginibacter as the type strain of a novel species, for which the name Mucilaginibacter daejeonensis sp. nov. is proposed.

\section{Description of Mucilaginibacter daejeonensis sp. nov.}

Mucilaginibacter daejeonensis (dae.jeon.en'sis. N.L. masc. adj. daejeonensis referring to Daejeon, Korea, the geographical origin of the type strain).

Cells are Gram-negative, facultatively aerobic, non-motile, non-spore-forming and rod-shaped, $0.6-0.8 \mu \mathrm{m}$ in

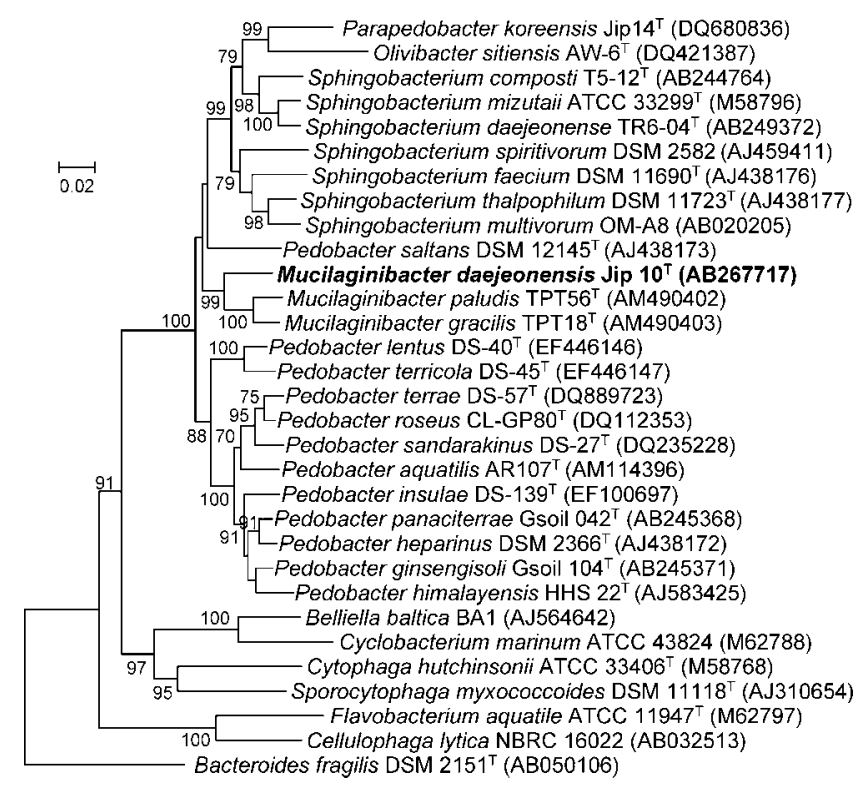

Fig. 1. Rooted phylogenetic tree based on the 16S rRNA gene sequences of strain Jip $10^{\top}$ and related bacteria in the phylum Bacteroidetes, made using the neighbour-joining method (Saitou \& Nei, 1987) with a distance matrix generated using the twoparameter model of Kimura (1983) and pairwise deletion. Bootstrap values (expressed as percentages of 1000 replications) greater than $70 \%$ are shown at branch points. Bar, 2 substitutions per 100 nucleotides. diameter and 1.3-1.6 $\mu \mathrm{m}$ long after 2 days on R2A agar. Colonies are opaque, circular, convex and orange in colour after 2 days on R2A agar. On R2A agar, grows at $15-37^{\circ} \mathrm{C}$, but not at 4 or $42{ }^{\circ} \mathrm{C}$. Growth occurs at $\mathrm{pH} 4.5-8.5$ and with up to $3 \% \mathrm{NaCl}$. Optimal growth occurs at $30{ }^{\circ} \mathrm{C}$, pH 7.0 and without $\mathrm{NaCl}$. Substrate utilization, enzyme production and other physiological characteristics are indicated in Table 1. In addition to the properties listed in Table 1, L-arabinose and rhamnose are utilized as sole carbon sources. Adipate, L-alanine, 4-hydroxybenzoate, caprate, L-fucose, glycogen, histidine, 3-hydroxybenzoate, 3-hydroxybutyrate, inositol, itaconate, 2-ketogluconate, 5ketogluconate, lactate, malonate, phenylacetate, L-proline, D-ribose, L-serine and suberate are not utilized as sole carbon sources. In API $50 \mathrm{CH}$ tests, acid is produced from $\mathrm{N}$-acetylglucosamine, aesculin ferric citrate, amygdalin, DLarabinose, cellobiose, gentiobiose, lactose, melibiose, methyl $\alpha$-glucopyranoside, starch, sucrose and turanose, but acid is not produced from adonitol, DL-arabitol, arbutin, dulcitol, erythritol, DL-fucose, glycerol, glycogen, inositol, inulin, D-lyxose, D-mannitol, melezitose, methyl $\alpha$-D-mannopyranoside, methyl $\alpha$-D-xyloside, potassium gluconate, potassium 2-ketogluconate, potassium 5-ketogluconate, raffinose, D-ribose, D-sorbitol, L-sorbose, salicin, D-tagatose, xylitol or L-xylose. According to the API ZYM gallery, positive for $N$-acetyl- $\alpha$-glucosaminidase, acid phosphatase, alkaline phosphatase, cystine arylamidase, esterase (C4), esterase lipase (C8), $\alpha$-galactosidase, $\alpha$ galactosidase, leucine arylamidase and valine arylamidase activities, weakly positive for $\alpha$-glucosidase and negative for chymotrypsin, $\alpha$-fucosidase, $\alpha$-glucosidase, $\alpha$-glucuronidase, lipase (C14), $\alpha$-mannosidase, naphthol-AS-BI-phosphohydrolase and trypsin. According to the API 20NE gallery, positive for arginine dihydrolase, urease, $\alpha$ glucosidase, protease, $\alpha$-galactosidase and glucose fermentation, but negative for nitrate reduction. The predominant respiratory quinone is MK-7. The major fatty acids are iso- $\mathrm{C}_{15: 0}, \mathrm{C}_{16: 0}$, iso- $\mathrm{C}_{17: 0} 3-\mathrm{OH}$ and summed feature 3 (iso- $\mathrm{C}_{15: 0} 2-\mathrm{OH}$ and/or $\mathrm{C}_{16: 1} \omega 7 c$ ). The DNA G + C content of the type strain is $40.4 \mathrm{~mol} \%$.

The type strain, strain Jip $10^{\mathrm{T}}\left(=\right.$ KCTC $12639^{\mathrm{T}}=\mathrm{LMG}$ $\left.23488^{\mathrm{T}}\right)$, was isolated from dried rice straw in a field in Daejeon city in South Korea.

\section{Acknowledgements}

This work was supported by the Key Project of Chinese Ministry of Education (no. 206039). We thank Jean Euzéby for his help with the etymology of the species epithet.

\section{References}

Buck, J. D. (1982). Nonstaining (KOH) method for determination of gram reactions of marine bacteria. Appl Environ Microbiol 44, 992993.

Felsenstein, J. (1985). Confidence limits on phylogenies: an approach using the bootstrap. Evolution 39, 783-791. 
Hall, T. A. (1999). BioEdit: a user-friendly biological sequence alignment editor and analysis program for Windows 95/98/NT. Nucleic Acids Symp Ser 41, 95-98.

Hiraishi, A., Ueda, Y., Ishihara, J. \& Mori, T. (1996). Comparative lipoquinone analysis of influent sewage and activated sludge by highperformance liquid chromatography and photodiode array detection. J Gen Appl Microbiol 42, 457-469.

Kim, M. K., Im, W.-T., Ohta, H., Lee, M. \& Lee, S.-T. (2005), Sphingopyxis granuli sp. nov., a $\beta$-glucosidase producing bacterium in the family Sphingomonadaceae in $\alpha-4$ subclass of the Proteobacteria. J Microbiol 43, 152-157.

Kimura, M. (1983). The Neutral Theory of Molecular Evolution. Cambridge: Cambridge University Press.

Kumar, S., Tamura, K. \& Nei, M. (2004). MEGA3: integrated software for molecular evolutionary genetics analysis and sequence alignment. Brief Bioinform 5, 150-163.

Mesbah, M., Premachandran, U. \& Whitman, W. B. (1989). Precise measurement of the $\mathrm{G}+\mathrm{C}$ content of deoxyribonucleic acid by high-performance liquid chromatography. Int J Syst Bacteriol 39, 159-167.
Moore, D. D. \& Dowhan, D. (1995). Preparation and analysis of DNA In Current Protocols in Molecular Biology, chapter 2, pp. 2-11. Edited by F. M. Ausubel, R. Brent, R. E. Kingston, D. D. Moore, J. G. Seidman, J. A. Smith \& K. Struhl. New York: Wiley.

Pankratov, T. A., Tindall, B. J., Liesack, W \& Dedysh, S. N. (2007). Mucilaginibacter paludis gen. nov., sp. nov. and Mucilaginibacter gracilis sp. nov., pectin-, xylan- and laminarin-degrading members of the family Sphingobacteriaceae from acidic Sphagnum peat bog. Int J Syst Evol Microbiol 57, 2349-2354.

Saitou, N. \& Nei, M. (1987). The neighbor-joining method: a new method for reconstructing phylogenetic trees. Mol Biol Evol 4, 406-425.

Sasser, M. (1990). Identification of bacteria by gas chromatography of cellular fatty acids, MIDI Technical Note 101. Newark, DE: MIDI Inc.

Stackebrandt, E. \& Goebel, B. M. (1994). Taxonomic note: a place for DNA-DNA reassociation and $16 \mathrm{~S}$ rRNA sequence analysis in the present species definition in bacteriology. Int J Syst Bacteriol 44, 846-849.

Thompson, J. D., Gibson, T. J., Plewniak, F., Jeanmougin, F. \& Higgins, D. G. (1997). The CLUSTAL_X windows interface: flexible strategies for multiple sequence alignment aided by quality analysis tools. Nucleic Acids Res 25, 4876-4882. 